\author{
Л. В. Куркина \\ Институт русского языка им. В.В. Виноградова РАН \\ (Москва, Россия) \\ lyukurkina@ramler.ru
}

\title{
RADA COSSUTTA. RIBIŠKA JEZIKOVNA IN KULTURNA DEDIŠČINA V TRŽAŠKEM ZALIVU IN SLOVENSKI ISTRI. KOPER, 2015. 277 S.
}

В монографии Р. Кошуты представлены в картографированном виде результаты исследования языкового и культурного наследия в сфере рыболовства в наречиях и говорах на Адриатическом побережье в районе Триестского залива и в словенской Истрии, где в новых условиях с изменением уклада жизни активно протекали и протекают процессы славян.-роман. лексической интерференции. Обследованы только словенские поселения в Италии в р-не Триестского залива (Križ, Kontovel, Nabrežina) и истровенецианские поселения на территории Словении (Piran, Izola). Обращение к терминологии рыболовства и культуре, связанной с этим промыслом, не случайно. С древних времен этот вид хозяйственной деятельности был важным дополнением к разведению скота и занятию земледелием, а «в некоторых богатых водами славянских краях рыболовство занимало первое место среди всех других отраслей хозяйства» [Нидерле 2000: 357]. В настоящее время в обследуемых регионах рыболовство занимает незначительное место, соответственно наблюдается сокращение численности рыбаков, отмечается, что человек, занимающийся рыбным промыслом в заливе Триеста, - большая редкость. Но старая, практически исчезнувшая форма хозяйственной деятельности продолжает жить в воспоминаниях, в рассказах старшего поколения, в домах хранятся как драгоценные реликвии предметы рыболовного промысла.

Обследование региона с целью получения и систематизации сведений о рыболовной лексике проводилось по программе проекта «Рыболовное наследие и языковое многообразие в альпийско-адриатическом просторе». Проект разработан в Институте лингвистических исследований г. Копер под руководством двух диалектологов - Фр. Креватин и Рады Кошутты, автора «Словенского диалектного лексического атласа словенской Истрии» [Копер, 2005-2006], «Словенского диалектного лексического атласа Тржашкой провинции» [Копер, 1987] и многих других исследований, посвященных диалектной лексике этого региона. В задачи 
работы входило изучение той части художественной литературы, в которой получило отражение рыболовство, анализ источников, связанных с этой темой, подбор информантов, знакомых с терминологией рыболовства, сбор диалектного материала по вопроснику «Диалектного атласа словенской Истрии и Краса» (436 вопросов). Вопросник охватывает следующие темы: море, геоморфология, метеорология, плавательные средства, растительный и животный мир моря. Результаты исследования представлены в виде монографии, основную часть которой (с. 25-245) составляют карты, показывающие распределение в разных пунктах рассматриваемой территории диалектных наименований, полученных от информантов и из других источников и записанных в словенской и итальянской фонетике. Большой интерес представляют связанные с рыболовством небольшие рассказы, записанные в дер. Криж в р-не Триеста (3 рассказа), Контовело (в 3 км к сев.-зап. от Триеста; 5 рассказов), Изола (ю.-зап. часть Словении; 2 рассказа). Каждый из текстов дан в трех вариантах: в записи на словенском диалекте, в переводе на словенский литературный язык и в переводе на итальянский язык. В текстах прослеживается сильное романское влияние на рыболовную лексику в словенских поселениях (ср. особенно записи из п. Изола), влияние со стороны словенского языка чрезвычайно редко. К монографии приложен список литературы, связанный с исследуемой темой, а также снятый автором и технически подготовленный Д. Мухич документальный фильм «Рыболовство Триестского залива и словенской Истрии» [Koper, 2015].

Культурно-историческая информация, открывающая вводную часть, помогает понять особенности той языковой ситуации, которая сложилась в словенскоитальянское пограничье с пестрым этническим составом (авторы Тина Рожац и Клара Шуменяк). В Приморье Крас был той территорией, где словенские племена в VIII в. впервые поселились в непосредственной близости от моря на землях, опустошенных чумой, многолетними войнами, где и по сей день сохраняются словенская культура, обычаи и язык. Глубокие традиции, связанные с рыболовством, отмечены в ряде деревень (ک̌kedenj, Barkovlje, Kontovel, Nabrežina, Sesljan, Štivan).

Из небольшой исторической справки читатель узнает, что на пол-ов Истрия, в настоящее время разделенном между тремя странами (Хорватия, Словения, Италия), славяне пришли с севера до VII в., и в то время население Истрии в языковом и этническом отношении представляло собой гомогенное образование, но уже в средние века здесь приходят в соприкосновение разные этнические группы, что повлияло на пестроту и разноликость говоров этой территории. После второй мировой войны прибрежная часть вместе с Приморьем отошла к Италии, и тогда в п. Изола и Пиран было более 200 рыбаков. После войны Истрия вошла в состав Югославии, что стало причиной переселения итальянских рыбаков Истрии в Италию. После распада Югославии Словения потеряла значительную часть морского побережья. В настоящее время в Изоле и Пиране по статистике 2005 г. в рыболовном промысле насчитывалось 142 рыбака. Во введении дается краткое описание поселений итальянских рыбаков в словенской Истрии (Изола, Пиран, Копер), венецианской части Истрии, где в 50-е г. ХХ в. в прибрежной части жили словенцы: в 1991 г. $4 \%$ населения — итальянцы, в 2002 г. - 2,8\%. 
В обследуемых регионах идет постепенное сокращение словенской части населения. Так, авторы характеризуя языковую ситуацию в восточной части Фурлании - Юлийском крае, отмечают, что в этом регионе вместе со словенцами и итальянцами сосуществуют этноязыковые меньшинства - фурланы и немцы. По данным 1958 г. здесь проживало 125 тыс. словенцев (из них в р-не Триеста 65 тыс.), в 1996 г. число сократилось до 61 тыс. (из них 25 тыс. в р-не Триеста).

В небольшой справке, приведенной во вступительной части, сообщается, что на современной словенской территории традиционно рыболовством занимались итальянцы, а на итальянской территории - проживающие там словенцы.

Словенские говоры в изучаемом регионе принадлежат приморской наречной группе, исследуемые по проекту пункты относятся к крашскому наречию, на котором говорят в западной части Краса и нижней части Випавской долины.

В работе представлен в словенской фонетической записи лексический материал, собранный в полевых условиях по вопроснику «Диалектного атласа словенской Истрии и Краса» в трех пунктах (Križ, Kontovel и Nabrežina) и в двух контрольных пунктах (Piran, Izola). Материал наглядно показывает, в каком объеме сохранилась лексика рыболовства в словенской части Истры и как распределяется лексика итальянского и словенского происхождения в этих двух небольших соседних регионах: в словенских поселениях большое количество терминов романского происхождения, тогда как в итальянских незначителен процент славянских рыболовных терминов. При живых тесных языковых контактах на небольшой территории, где населенные пункты расположены не так далеко друг от друга (ср. Изола и Пиран разделяют 10 км), сложилась рыболовная терминология из словенских и итальянских слов для обозначения реалий рыболовного промысла.

Словенская рыболовная терминология сохранилась в очень ограниченном объеме, что вполне объяснимо: рыболовство утратило статус основной формы хозяйственной деятельности. Вместе с угасанием рыболовства выходят из активного употребления и термины. Как показывают приведенные материалы, словенская лексика рыболовства сохранилась лишь в р-не Триестского залива, практически в словенской Истре отсутствуют наименования словенского происхождения.

Многие карты наглядно показывают отсутствие словенских и итальянских терминов рыболовства во всех или отдельных обследуемых поселениях Триестского залива. Приведем некоторые примеры из основных разделов вопросника:

«море»: к. 16 (Kontovel);

«метеорология»: $41 \mathrm{a}), 41$ b) (Kontovel), 45 (Kontovel);

«навигация»: 64 (Nabrežina);

«судно»: к. 82 и 94 (Nabrežina), к. 99 (Nabrežina, Križ), к. 103 (Nabrežina), к. 104 (Nabrežina, Križ), к. 105 (Nabrežina), 109 (Nabrežina), к. 110 ((Nabrežina, Kontovel), к. 111 и 112 (Križ, Kontovel), к. 122 (Nabrežina), к. 127 (Nabrežina), к. 138, 139, 140 (Kontovel), к. 136, 137, 151, 153 (Nabrežina), к. 154 и 155 (Nabrežina), к. 167, 175 (Nabrežina), к. 177 (Nabrežina, Križ), к. 180 (Nabrežina), к. 181 и 182 (Nabrežina), к. 183 (Nabrežina, Kostovel), к. 184 (Nabrežina), к. 185, 194 и 195 (Nabrežina, Križ), 
к. 190 (Nabrežina), к. 192 и 193 (Nabrežina), к. 196 (Nabrežina), к. 202 (Nabrežina), к. 203 (Nabrežina, Kostovel), к. 204 и т.д.;

«рыбная ловля»: к. 238 (Kontovel), к. 242;

«названия животного и растительного мира»: к. 300 и 301 (Nabrežina, Križ), к. 302, 303 и 304 (Kontovel), к. 305, 310, 312 (Križ, Kontovel), к. 314 (Križ, Kontovel), к. 360 (Nabrežina, Križ), к. 370 (Nabrežina, Križ), к. 401 (Nabrežina, Križ), к. 406 (Križ, Kontovel), к. 415 (Nabrežina), к. 416 (Nabrežina), к. 423, 431, 432, 436 и т. д.

Можно отметить, что в этом регионе лучше сохранились словенская лексика из разряда «метеорология», «рыбная ловля», в меньшей степени она присутствует в составе обозначений животного и растительного мира.

Параллельно прослеживается вытеснение словенских лексем, замена их итальянскими. Так, только итальянские слова используются при обозначении мили, морской меры длины (к. 87), разных видов плавучих средств (к. 88), кормы (к. 90), носа корабля (к. 89), разных частей рыболовецкого судна (к. 93, к. 94, к. 95), надводной части судна (к. 99), палубы (к. 103), боковой части (к. 102), трюма (к. 107), перегородки на судне (к. 109), судостроительной верфи (113 а), долота (к. 125), маленького якоря (к. 145), подъемного крана (к. 149), руля (к. 150), подпорной части руля (к. 152), цепи (к. 161), уключины (к. 176) и т.д.

Сильное романское влияние проявляется в сосуществовании исконно словенских и итальянских терминов в близлежащих поселениях и даже в одном говоре: ср. обозначение подводной части судна — исконное d'no и итал. $k \underline{z}$ 'rena (к. 92), в значении 'смола' словен. s'mola и итал. 'pẹlà (<pégola) (к. 121), ‘пакля’ - словен. predivo

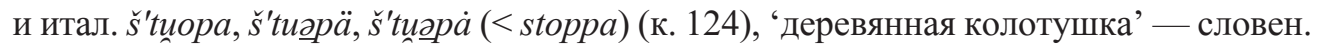

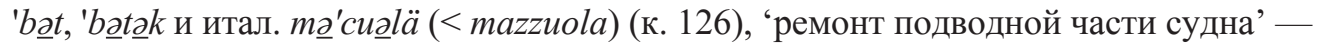

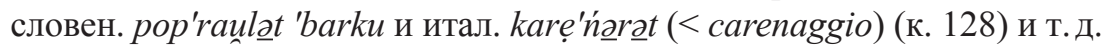

Единичны случаи с использованием только словенских лексем во всех обследуемых точках в качестве обозначения той или иной реалии рыболовной сферы: ср. в значении 'лопасть весла' lu'pata, lą'patä, lu'patá < lopata (к. 168), 'veslo / 'väsluä / 'vjäslua / v'jəslà pl. 'весло / весла' (к. 165), ‘два весла' — d'vej 'vesli, 'duajna v'jassla (к. 169), 'гребец’ - vass'lač (к. 174). Исконно словенская лексика, унаследованная из древней эпохи, присутствуют в названиях сети: (к. 257) 'varša / varšä / 'varša < *vbrša [Bezlaj IV: 363], (к. 258) m'rieža / m'riežä / m'rejžà / m'ręža < *merža (Bezlaj II: 201); в наименованиях разных частей, деталей пловучего судна: (к. 220) vәzu 'узел' < *vozlъ [Bezlaj IV: 347], (к. 221) 'zanka / 'zankä 'затяжная петля' < *zamъka *zamsknoti [Bezlaj IV: 388-389], (к. 164) za'vora / zə'vuorä / zəvọá 'тормоз' < *zavora *vorъ [Bezlaj IV: 344], (к. 142) pot'jegənt / put'jəynət 'guər žə'lejzuá 'потянуть вверх якорь' < potegnoti и pu'lejč žə'lejzud < *povelkt'i 'потянуть вверх якорь', (к. 134) žə'lezo / žə'lejzuа் 'якорь' < *železo, (к. 135) ob'roč 'якорный рым' < *ob-ročb * roka [Bezlaj II: 237] и т.д.

Сохранившиеся фрагменты словенской лексики рыболовства дают материал для изучения проблемы лексической интерференции. Этот материал открывает новые грани в семантическом развитии словенской лексики, парадигматических отношений в языке и т. п. Остановимся на некоторых примерах. 
Так, в некоторых сочетаниях словенские лексемы функционируют в значении, неизвестном словенскому языку и вообще славянским языкам. Наблюдаемые семантические сдвиги в словенской терминологии обусловлены в значительной степени итальянским влиянием.

Примером может служить карта №3 под названием «Бурное море» (с. 27). В значении ‘бурное море' в р-не Триеста отмечено необычное не только для словенского языка сочетание 'gardo 'murje. Словен. grd 'гадкий, безобразный, противный' и его славянские соответствия, употребляемые по отношению к человеку [ЭССЯ 7: 206-207], в данном сочетании приобретает метафорическое значение не без влияния итал. mare agitato, grosso 'беспокойное, бурное море': море воспринимается как одушевленное, живое существо с проявлениями, свойственными человеку.

В районе Триеста мелкое море обозначается сочетанием 'niska 'uoda (карта 6). Нигде более не отмеченное на славянской территории [ЭССЯ 25: 151-152] использование прилаг. *nizъkъ(jb) для обозначения морского мелководья, видимо, является семантической калькой итал. mare basso, cp. acque basse 'мелководье'. Под влиянием итал. mare profondo - mare basso в словенских диалектах этого региона складывается противопоставление *nizъkъ(jb) — * globokъ(jb) (cp. globoko morje).

В значении 'берег' отмечено в р-не Триеста словен. kraj: 'gremo h k'raji (к. 8). Это значение, известное также некоторым диалектам на территории Македонии, Польши и др. (см. ЭССЯ 12: 88-89), явилось результатом переосмысления исходного значения, мотивированного семантикой производящего гл. *krojiti 'резать', т. е. берег как конец, край земли. Таким образом семантическая изоглосса обнаруживает продолжение в западной части ю.-слав. ареала.

Словен. s'viesla 'деревянное ведро' (к. 158: Nabrežina, Križ), вероятно, сохраняет старое значение, отмеченное еще в словаре Tрубара (XVI в.): pet fvifli 'piscina quinque porticus habens' при более распространенном употреблении этого слова в качестве строительного термина: ср. словен. svisli 'подстрешье; стог сена', чеш. svisel 'треугольная стена на сторонах козолца' и т. д. < *sъvislъ, далее к *visěti [Bezlaj III: 352].

Лексема škripec, более известная в метафорическом употреблении, сp. $v$ škripcih biti 'оказаться в неловком положении' [Bezlaj IV: 70-71], употребляется в функции технического термина: ср. šk'ripc ‘блок’ (к. 191), šk'ripčeuje ‘одно из обозначений ворота' (к. 157).

Функцию рыболовного термина выполняют не только отдельные лексемы, но и сочетания, небольшие предложения, как правило, с включением итальянских слов. Ср. že'lazzo 'uarje, že'lejzuá 'uәrjà pud 'barku 'якорь волочится по дну' (ср. итал. l'ankora ara il fondo) (к. 143); 'lou z 'bombi 'лов с использованием взрывчат-

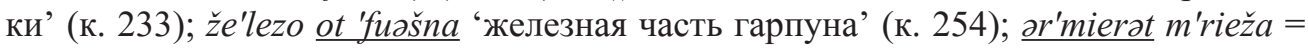
'armare le reti' (к. 272), g'remo 'largo 'идем в открытое море' (к. 7) и т.п.

Детально проанализированная в книге рыболовная лексика в районе активных межъязыковых контактов на крайней юго-западной периферии славянского мира предстает на широком славянском фоне как один из фрагментов исследований 
большой тематической группы, изучаемой на материале отдельных языков или всех славянских языков (ср. Коломиец 1986 с библиографией).

Нельзя не отметить высокое качество оформления представленного в книге материала. Тщательно выполненные карты дают наглядное представление о составе лексики рыболовства и процессах, которые привели к формированию смешанных наименований и вытеснению исконно словенской лексики.

\title{
Литература
}

Коломиец 1986 - Коломиец В. Т. Происхождение названий рыб. К IX Международному съезду славистов. Киев: Наукова думка, 1986.

Нидерле 2000 - Нидерле Л. Славянские древности. Перевод с чешского Т. Ковалевой и М. Хазанова. М.: Алетейа, 2000.

ЭССЯ - Этимологический словарь славянских языков. Праславянский лексический фонд. Вып. 1-40-. Под ред. О. Н. Трубачева, А. Ф. Журавлева, Ж. Ж. Варбот. М.: Наука, 1974-2016-.

Bezlaj - Bezlaj F. Etimološki slovar slovenskega jezika. Vol. I-V. Ljubljana, 19762007.

\author{
Lyudmila Kurkina \\ V.V. Vinogradov Russian Language Institute \\ Of Russian Academy of Sciences \\ (Moscow, Russia) \\ lyukurkina@rambler.ru
}

\section{REVIEW OF LINGUISTIC AND CULTURAL HERITAGE IN FISHERIES IN THE GULF OF TRIESTE AND SLOVENIAN ISTRA}

\section{References}

Bezlaj F. Etimološki slovar slovenskega jezika [Etymological Dictionary of Slovenian Language]. Vol. I-V. Ljubljana, 1976-2007. [In Slovenian].

Etimologicheskii slovar' slav'anskih jazykov. Praslav'anskii leksicheskii fond. [Etymological Dictionary of Slavic Languages. Proto-Slavic Lexical Stock]. Vol. 1-40-. M.: Nauka. 1974-2016-. [In Russian].

Kolomiec V. T. The origin of the names of fish. IX International Congress of Slavists. Kiev, 1986. [In Russian].

Niderle L. Ancient Slavic. Translation from Czech. M., 2000. [In Russian]. 